\title{
Integration of balanced scorecard and data envelopment analysis to measure and improve busi- ness performance
}

\author{
Jarmila Horváthováa ${ }^{\mathrm{a}}$ Martina Mokrišová ${ }^{\mathrm{a}^{*}}$ and Mária Vráblikováa
}

${ }^{a}$ Faculty of Management, University of Prešov, Prešov, Slovakia

\begin{tabular}{l}
\hline C H R O N I C L E \\
\hline Article history: \\
Received: April 16, 2019 \\
Received in revised format: April \\
282019 \\
Accepted: May 15, 2019 \\
Available online: \\
May 16, 2019 \\
\hline Keywords: \\
Balanced Scorecard \\
Data Envelopment Analysis \\
Financial perspective \\
Goal \\
Key performance indicators \\
Performance
\end{tabular}

Performance

\begin{abstract}
A B S T R A C T
The paper addressed the following research problem: Is the DEA (Data Envelopment Analysis) a suitable method of measuring and improving the performance of a company? Is it possible to calculate the goal values of the key performance indicators based on the BSC (Balanced Scorecard) principles using the DEA results? Is it possible to link the results of the BSC method and the DEA method to increase business performance? The aim of the research was to find out which financial indicators of the company are key performance indicators. We selected the key performance indicators using the BSC principles. These indicators were then applied as inputs/outputs in the DEA model. The partial aim was also to propose goal values for selected key performance indicators. The analysis was carried out on a sample of companies operating in the sphere of heat industry in Slovakia. The sample was created to represent businesses that have problems with their performance as well as those who do not have any problem. When choosing the sample, we made use of Altman's Z-score. We then calculated the values of the selected financial indicators. The correlation matrix and the BSC principles were applied to select key performance indicators. We also made use of the DEA method. This nonparametric method can be applied in the field of business efficiency, financial health, and performance evaluation. The DEA CCR input-oriented model was designed. We see the application of the DEA method in assessing financial health and performance of a company as well as the DEA CCR model itself as the main contributions of this paper. The research also paid attention to the calculation of the goal values of key performance indicators that enter the BSC as goal values. Using these goal values, a company may become more stable and therefore competitive. This research confirmed the possibility of integrating BSC and DEA.
\end{abstract}

\section{Introduction}

In the $21^{\text {th }}$ century companies face many problems and challenges. Due to the current market saturation, it is important for them to maintain and further develop their competitive advantages (e.g. innovations, quality of products and customer services, human capital etc.) and to ensure that all improvements are reflected in their financial situation, their level of competitiveness or even the overall existence. These facts are reflected in the current modern management trends - the shift from the reactive management to more proactive one based on planning and predicting changes in the market, a shift from unsystematic 
and random problem solving to systematic one, which is characterized by a detailed analysis of a problem. Trends in management move from hard to soft components with an emphasis on creativity and the development of human potential in innovative ways such as coaching and e-learning. Instead of partial approaches, systematic approaches are applied. These are aimed at understanding a company as an organism, in which individual business areas cannot be separated from each other. Within these approaches we can mention the Balanced Scorecard concept. The understanding of business performance expressed by financial indicators is replaced by its understanding as a penetration of three dimensions (E-E-C): Efficiency - customer needs satisfaction, Effectiveness - management and optimal use of resources and Changeability - strategic awareness of managing changes. These three dimensions are also a great prerequisite for introducing the Balanced Scorecard.

The next part of the text is structured as follows: The first section outlines the theoretical basis of the studied problem. This part of the article lists selected aspects of the BSC. A special part is devoted to the summary of the theoretical knowledge from the field of integration of BSC and DEA methods. At the end of the theoretical part a research problem and goal are formulated. The second section describes the data, the analysed sample of companies and the processing methods. When addressing the research problem, we made use of selected financial indicators, correlation matrix, Altman model, DEA method and BSC method. We formulate dual input-oriented DEA CCR model which was solved in MS Office. The third section includes results and discussion of the results achieved. This section lists the performance values of the selected sample of companies as well as the goal values of selected key performance indicators. The final part of the article is the conclusion in which the essential conclusions resulting from the research problem are addressed.

\section{The essence and development of Balanced Scorecard}

A preferred area of interest for managers at the end of the 20th century was the measurement of business performance. The question was how to measure the performance but not to improve one part of the business to the detriment of another, and to make the performance measurement system a management tool that supports continuous improvement (Gavurová, 2011). The aim was to replace or complement the financial indicators so that the performance measurement was not focused only on the financial area.

The limitations of financial data as the basis for companies' decision-making has been recognised long time ago (Dearden, 1969, In: Lawrie \& Cobbold, 2004) along with the ability to utilise non-financial data in providing for improved decisions (Committee on Non-Financial Measures of Effectiveness, 1971; In: Lawrie \& Cobbold, 2004). "It seems that the traditional business performance management based primarily on financial management has reached its limits and in recent years we have seen the development of new non-traditional indicators, methods and models based primarily on non-financial methods, in particular on strategic and other qualitative indicators" (Rajnoha et al., 2016, p. 183). Horváthová and Mokrišová (2017) state that the first to use non-financial indicators to assess the performance of the company were Peters and Waterman (1982) (in the form of 8 success factors), followed by Bullen and Rockart (1981) and Chung (1987) who came up with critical success factors. The problem is how to identify all possible non-financial measures. One of the solutions was the Balanced Scorecard (Kaplan \& Norton, 1992) that has become both well-known and widely adopted (Rigby, 2001, 2003; Dumitrescu \& Fuciu, 2009) Kaplan and Norton presented Balanced Scorecard as an integrative device that would encourage and facilitate the use of non-financial information.

The Balanced Scorecard was at first a simple 4-component approach to measuring business performance. Three other areas were then added to the financial area: Learning \& Growth, Internal Business Processes, and Customers. These areas represent 3 main stakeholders (Cobbold \& Lawrie, 2002).

The basic idea of the Balanced Scorecard was to create a network of strategic causal relationships between perspectives. The financial perspective refers to profitability goals. The customer perspective 
points to customer preferences and identifies product or service requirements to create value for the goal customer segment. The perspective of internal processes refers to production, sales and distribution processes. The perspective of learning and growth points to organizational abilities and intangible assets of the company (Kaplan \& Norton, 2007; Clegg \& Bailey, 2008). The causal relationship between perspectives is explained by Petrrík (2009). The perspective of learning and growth influences the perspective of internal processes which in turn affect the perspective of customers which ultimately affects the financial perspective. It can be said that the quality of human capital (the perspective of learning and growth) is the cornerstone of business prosperity (the cause) while the financial perspective is the result.

The basic characteristic of BSC is balance in different directions. Hasan and Tibbits (2000); Lesáková (2004); Nair (2004); Tjader et al. (2014) see the balance in the following: between the short and long term business objectives, past, present and future of the company, between financial and non-financial indicators, between leading and lagging indicators and between external and internal performance factors.

Since 1992, the Balanced Scorecard has gone through 3 development phases (generations). Firstly, the BSC method was used as a business performance measurement and management system (Kaplan \& Norton, 1992). Later, the method was extended to implement the strategy by linking the strategic objectives of the company, identifying the causal relationships between the measures and determining the responsibility for the achieved objectives, i.e. the BSC method served as a tool for implementing the strategy (Kaplan \& Norton, 1996; Olve et al., 1999). Currently, the third BSC development phase (generation) is at its peak. BSC is seen as a strategic management tool linking vision, mission, and strategy with set goals within individual perspectives. The BSC method has also been broadened to define scenarios that complement the causal relationship between perspectives. We can say that BSC is becoming a strategic asset management tool (Gavurová, 2011, 2012; Lawrie \& Cobbold, 2004; Andersen et al., 2004).

As Corporate Social Responsibility concept (CSR) is becoming more and more important, there is a space for the latest, fourth generation of BSC. In addition to the four known perspectives, BSC should also include an external perspective taking into account the environmental and social aspects. The environmental aspect is an external complement to the financial perspective while the social aspect is complementary to the customer's perspective - the company brings benefits not only to customers but to the entire community (Kádárová et al., 2015).

\subsection{Sources of information and performance measurement capabilities of individual BSC perspectives}

The financial perspective focuses on the financial health of the company (Werner \& Xu, 2012). Its basis is formed by the financial and economic analysis of the company. The basic task of any financial analysis is to provide information about the financial situation of the company, its stability and performance at the right time. By analysing the past and the present situation of the company, the analyst can identify potential risks and can therefore formulate and implement the right decisions that can eliminate negative developments in the future. Information obtained from the financial analysis can be used by different users, managers, employees, banks, creditors, real or potential investors, state authorities, the public, sometimes even competitors. The purpose of the financial analysis is not only to know the past financial situation through ex post analysis but also to predict the future development of the company through an ex ante analysis (Zimermanová \& Bartková, 2016). Under the BSC, Lesáková (2004) considers the following to be the most appropriate financial performance indicators: a set of financial ratios (indicators of liquidity, profitability, indebtedness, activity, market value), Economic value added (EVA) or IN and INFA (IN Financial Analysis) models.

Kaplan and Norton (1992); Mooraj et al. (1999); Horváthová and Suhányiová (2012) distinguish between the use of financial indicators at different stages of the company's life cycle. In the growth phase of the 
business, the financial indicators may focus on the cost of developing new products or distribution channels. During the maintenance phase, we use traditional financial methods (e.g. Return on equity, operating and gross profit, static and dynamic methods of investment valuation using discounted cash flow). There is a pressure on the cash flow in the collection phase, since indicators such as Return on Investment (ROI), Economic Value Added (EVA), and operating profit are no longer of such value because the largest investments have already been made.

Customers form the external environment of the business. Sometimes it is difficult to get relevant information about them. It is therefore necessary to use marketing research techniques, customer satisfaction surveys (e.g. KANO model) or marketing intelligence to analyse competitors, markets, partners and technology (Zimermanová \& Bartková, 2016).

Lesáková (2004) and Kaplan and Norton (2007) state that with regard to the customer perspective we can use the following measures: market share, which can be expressed by the number of customers, volume of sales or number of products sold, new customers acquisition - measuring the number and proportion of new customers or new orders in absolute or relative terms, customer loyalty - monitors the rate of maintaining good relationships in the company in absolute or relative terms, customer satisfaction - monitors customer satisfaction rate, customer profitability - measures net profit per customer / market segment after deducting customer / market support costs.

According to Lesáková (2004) and Kaplan and Norton (2007), the key processes in the company are made up of follow-up activities of the value chain and consist of 3 processes - the innovation process, the operation process and the after-sales service. As for the innovative process, the authors recommend using instruments such as the time necessary for the development of the new generation of the product, the level of inventions (Valent's innovation spectrum), the time it takes to place a product on the market. However, the innovation process is closely related to other perspectives.

As for the operating process, which starts with an order and ends with the delivery of a product to a customer, we can focus on the quality of the operating process, the cost of the operating process and the machine utilization. After-sales service comes after the product is delivered to the customer. Under this process we can measure quality or speed of service (Lesáková, 2004; Kaplan \& Norton, 2007).

The basic building block of the BSC methodology is the perspective of learning and growth. At present, people in the companies are no longer seen as a cost item but as the most important intangible asset that needs to be valued and invested in. It is the human potential (learning and growth) that is the basis for the development of all business areas (Blašková, 2011). According to Kaplan and Norton (2007), the perspective of learning and growth consists of 3 core areas: employee competences, the ability of the information system, delegation of authority and engagement. According to Horváthová and Suhányiová (2012), this perspective, which is focused in the future, measures, in addition to the strategic potential of information systems, the potential of employees, their motivation and the system of their goals. This perspective develops goals and measures that support learning and growth of employees.

According to Horváthová and Suhányiová (2012) and Kaplan and Norton (2007), in addition to traditional employee indicators (e.g. employee satisfaction, employee productivity, average monthly income, benefit level, turnover), it is important to measure also indicators such as education, motivation, flexibility or ability to work in a team.

\subsection{Advantages, barriers and sustainability of BSC implementation}

Lesáková et al. (2017) investigate the causes of interest or disinterest of Slovak companies in implementing the BSC. The most common causes of concern regarding BSC include the complexity of measuring 
business performance and its relevance in the future, linking strategic and operational decisions to everyday practice, improving business process efficiency, and eliminating barriers between strategy formulation and implementation. The most common reasons for not taking part in the BSC include low awareness of this method, the lack of strategic management, management techniques implemented according to the current market situation, and the use of other methods to measure business performance.

Gavurová (2011) examines the Slovak companies and implements BSC for companies (agencies) whose scope of business was advising on the implementation of BSC in practice. She found that up to $3 / 4$ of Slovak companies with BSC were owned by a foreign investor, $71 \%$ were industry and trade-oriented and mostly they were medium to large companies using at least some form of strategic management. Among the most common reasons for implementing BSC is the introduction of a strategy into practice and performance measurement in all areas of business, among less frequent reasons are process monitoring or setting the informative value for financial indicators. In 2011, there were 16 consultancy agencies introducing the BSC concept into practice, $62.5 \%$ of which belonged to micro-enterprises and some of them have existed since 1992, i.e. since the introduction of BSC.

According to Horváthová and Suhányiová (2012) BSC's business management benefits can be divided into two core levels: the management level: focusing on key issues and contexts, focusing on reporting strategically important information, linking business management and strategies through goals, uniting employees, customers, business results, and processes in the enterprise into one purposefully functioning whole; and at the communication level: the employees of the company are better acquainted with the strategies, their own work and strategies are more integrated, the level of IT use is improved at all levels of management.

The benefits of BSC implementation are also addressed by Quesado et al. (2018). They state that a comprehensive enterprise performance analysis (leading and lagging system) that provides a holistic vision, the process of defining and communicating priorities to managers, employees, investors and customers, and the consistency between strategic goals and indicators are the most profound advantages.

Implementation of the BSC may also entail certain risks. Problems with BSC implementation can occur at each stage of implementation. Gavurová (2012) sees the main problem areas as follows: in the strategy formulation phase, the company may lack appropriate strategic analytical methods, the company management may have problems with defining critical success factors or the main competitive advantage. In the BSC formulation phase, the management of the enterprise may experience problems with choosing the right key performance indicators (KPIs) in terms of strategic goals, target setting, management knowledge of BSC deployment, and implementation of employee supervision by business management. In the implementation phase, the problem with redefining the reporting process can arise. In the last phase, the phase of implementation, there may be problems with the assessment of BSC and harmonization of the BSC system.

The long-term use and sustainability of performance measurement within BSC is also addressed by Madzík (2017). In order to reach the goal values during a certain period of time, we should periodically monitor the development of these values as they grow or decrease according to the nature of the indicator - minimalistic (e.g. Debt ratio) or maximalistic (profitability indicators) and whether the change is uniform, progressive or depressive. It is therefore possible to divide the reference period, for example, into 10 equal time slots and to determine for each time period the reference value of the indicator (it can be higher or lower), which we can express in absolute or relative terms, or calculate the current state of the development of the goal value - performance index. Vrábliková (2017) also states that at the end of the reference period it is possible to calculate the performance of each BSC perspective in \%, depending on the rate of fulfilment of the set goal values. If the perspective performance is less than $100 \%$, the company has a weak position in the given field. This fact may be turned into a new innovation opportunity in the next period. The author also recommends that the objectives in individual perspectives should be weighed 
according to stakeholders' priorities, but the prospects within BSC as a whole should be balanced and equivalent. According to Gallo (2017), in the case of a high-quality BSC, analysts or controllers have already broken down strategic goals and their metrics into the so-called drivers. The drivers have a significant impact on the creation of a given indicator, make it possible to check whether the strategic goals are being met effectively and their analysis can tell why they are met and who is responsible for it.

\subsection{DEA as an innovative way to measure business efficiency and performance}

As we have already outlined within the Balanced Scorecard concept, business performance is closely related to minimizing inputs (or goal values of indicators such as operating costs) and maximizing outputs (or goal values of indicators such as sales of products), i.e. with efficiency which is the ratio of outputs and inputs.

In 1957, Farrell came to the idea of improving the way in which companies evaluate their performance (efficiency). He considered the methods used at that time, such as the measurement of labour productivity or capital productivity, to be limiting because they did not cover the possibility of combining multiple inputs and thus were not sufficient to express the overall rate of efficiency of the company. These deficiencies have resulted in a more relevant approach applicable to any organization and thus widened the concept of productivity to include a more general concept of efficiency. He was inspired by the work of Vilfred Paret, where his theory of prosperity considered apart from the increments and decreases also their importance and assigned them some weights - this principle is now known as the Paret criterion. Farrell is, therefore, considered the father of the DEA method. The method is based on the principles of linear programming. The basic task of the DEA models is to benchmark the Decision Making Unit (DMU) within the group of units with the same or a similar focus. The DMU definition is relatively flexible. DMU is responsible for converting inputs into outputs the efficiency of which needs to be evaluated (Cooper et al., 2011; Cooper et al., 2007).

Klieštik (2009) explains that input-oriented approaches detect efficiency based on input variables. To improve efficiency, the company should reduce inputs. Its counterpart is the output-oriented approach that recommends increasing the volume of outputs to improve efficiency. Another DEA model breakdown criterion is returns to scale. Constant returns to scale (CRS) occur if an increase in input of 1\% results in an increase in output of 1\% (CCR models - Charnes et al. 1978). Variable returns to scale (VRS) occur if an increase in input of $1 \%$ results in an increase in output of more or less than $1 \%$ (BCC models - Banker et al. 1984).

Measuring enterprise efficiency using DEA models has various advantages and disadvantages. Among the benefits, Majorová (2007) and Klieštik (2009) include mainly work with multiple inputs and outputs. There is no need to ensure normal distribution of data. Identification of ineffective companies is relatively fast. Disadvantages include inefficiency deviations, which may be due to statistical distortion and a nonparametric approach, where it is difficult to test the hypotheses regarding inefficiency and structure of production functions. In the long run, an ineffective company can become effective by adopting certain rationalization measures, and vice versa. Therefore, until recently, one of the disadvantages of DEA was also considered its limited variety. Therefore, the Malmquist index, named after the Swedish economist Sten Malmquist, was created to measure changes in business efficiency over time. This index, which was first modified for business efficiency measurement by Färe et al. (1992), can also be used in various variants: output-oriented, input-oriented with constant or variable (increasing or decreasing) returns to scale.

\subsection{Mutual integration of BSC and DEA}

With the increasing popularity of both BSC and DEA, there came several studies that examined their implementation with regard to the evaluation of the performance and efficiency of industrial companies 
and their processes. Given the planned establishment of the systematic relationship between these two methods, it is necessary to summarize their fundamental differences, advantages and disadvantages in the following table (Table 1).

Table 1

Comparison of BSC and DEA

\begin{tabular}{|c|c|c|}
\hline Compatibility & BSC & DEA \\
\hline Way of comparison & comparison with an ideal virtual unit & proportional comparison the same units \\
\hline View & multiple view & input / output \\
\hline Mathematical ranking & weak & strong \\
\hline Applicable process & self assessment of organization & technical efficiency \\
\hline Accuracy of measurement & moderate & high \\
\hline Presenting of improvement method & moderate & high \\
\hline Ranking & does not support & has \\
\hline Future view & has & doesn`t have \\
\hline Regarding to organization strategy & has & has \\
\hline
\end{tabular}

Source: Aryanezhad et al. (2011)

The first major study devoted to BSC and DEA, is the study by Rouse et al. (2002). The authors used DEA and constructed a performance pyramid based on the BSC method that was designed to measure efficiency. The model of the relationship between the perspectives of BSC and DEA was addressed by Walderrama et al. in 2009. In 2010, Lotfi et al. used in their research the CINDB (Combined Interval Net DEA and BSC) method for performance evaluation along with financial and non-financial indicators. These indicators were identified with application of the BSC method and used as inputs and outputs in the DEA model. According to Memari et al. (2014), the BSC and DEA integrate into three levels: strategic goals (Effectiveness goal), optimizing the use of resources to generate the required outputs (Efficiency goal), and balancing between different aspects of business with regard to causal relationships between perspectives (Balance goal). Asgari et al. (2017) studied the integration of BSC and DEA. The authors tried to find the most suitable instruments for connecting the BSC and the three-step DEA model. The BSC indicators have been used as inputs/outputs of the DEA.

Durkáčová and Kádárová (2014) suggested the way to integrate BSC and DEA. BSC consists of 4 perspectives (in the case of the 4th generation we should consider the 5th perspective - external perspective) which contains individual strategic objectives. The company can then assign individual perspectives weights using, for example, an analytical hierarchical process or pairing method, and the same can be done with KPIs according to manager's preferences. Within the DEA model, individual KPIs can then be broken down into: KPIs as inputs and KPIs as outputs. Finally, it is possible to identify and compare the effectiveness of each DMU within the industry under consideration. Aryanezhad et al. (2011), however, chose another approach to BSC and DEA integration using the two-step DEA model. Firstly, they recommended to measure the effectiveness of individual perspectives for selected DMUs (for example, in the perspective of learning and growth, the share of motivation payments and the share of trained employees are listed as inputs, and the percentage increase in employee capabilities and the speed of services provided are listed as outputs). Then, using two-step DEA model for selected DMU, it is necessary to evaluate effectiveness between perspectives through mutual correlations.

We have decided to do this research because we are interested in improving business performance applying BSC method. During working with DEA model we realized, that this model can suitably complement the BSC and these two approaches can work together in perfect harmony.

Compared to Rouse et al. (2002), who first applied DEA model and then built performance pyramid using BSC, we applied the reverse procedure. First we applied BSC method to identify key performance indicators. Then we divided indicators to inputs and outputs and applied DEA model to evaluate performance and calculate goal values. This approach is innovative because we have been able to calculate 
goal values of inputs and outputs to improve the performance of analysed businesses with the use of both methods. Certain limitation for us was the lack of information from all BSC perspectives, therefore we processed in detail only financial perspective. Addressing other perspectives is our goal for the future. In line with the topic of the paper and the theoretical background as well as the studies that have been carried out in the given field and their results, we have set the research problem.

Research problem: Is the DEA method a suitable method of measuring and improving business performance? Is it possible to calculate the goal values of the key performance indicators based on the BSC principles using the DEA results? Is it possible to link the results of the BSC method and the DEA method to increase the performance of the company?

The aim of the research was to find out which financial indicators of the company are key performance indicators. We selected the key performance indicators using the BSC principles. These indicators were then applied as inputs/outputs in the DEA model. The partial goal was also to propose goal values for selected key performance indicators.

\section{Data and methodology}

The research input database consisted of data from 497 companies active in the field of heat supply in Slovakia. A more detailed analysis of the database data excluded 154 companies, due to the negative value of equity and other weaknesses in the data. Due to the extreme values of some selected financial indicators, 48 companies were subsequently excluded from the sample. The resulting sample, which was analysed under the research, consisted of 295 companies. The sector that has been analysed is important both economically and socially and plays an important role in the everyday life of society and consumers. All companies in this sector are local suppliers of heat. Some companies have a monopoly position in their respective geographical areas. Despite some similarities with other energy sectors, heat cannot be traded as a commodity between countries and due to significant heat losses in transmission and distribution, it cannot be traded between networks existing in various locations. The overall character and structure of the heat economy as well as the way of supplying heat and hot water are given in different geographic areas by various factors, including: climate and landscape diversity, historical development, demographic conditions and territorial division, private, commercial and industrial character of constructions, economic activity or availability of fuel sources for heat production. Based on the above factors, we encounter different structure and heat supply systems in each larger city or municipality. Each particular system is also constituted by its own set of thermal devices (Antimonopoly Office of the Slovak Republic, 2013). These facts are a prerequisite for the existence of risk factors that affect the performance of the analysed companies from the outside.

The process of the research problem-solving is shown in Fig. 1.

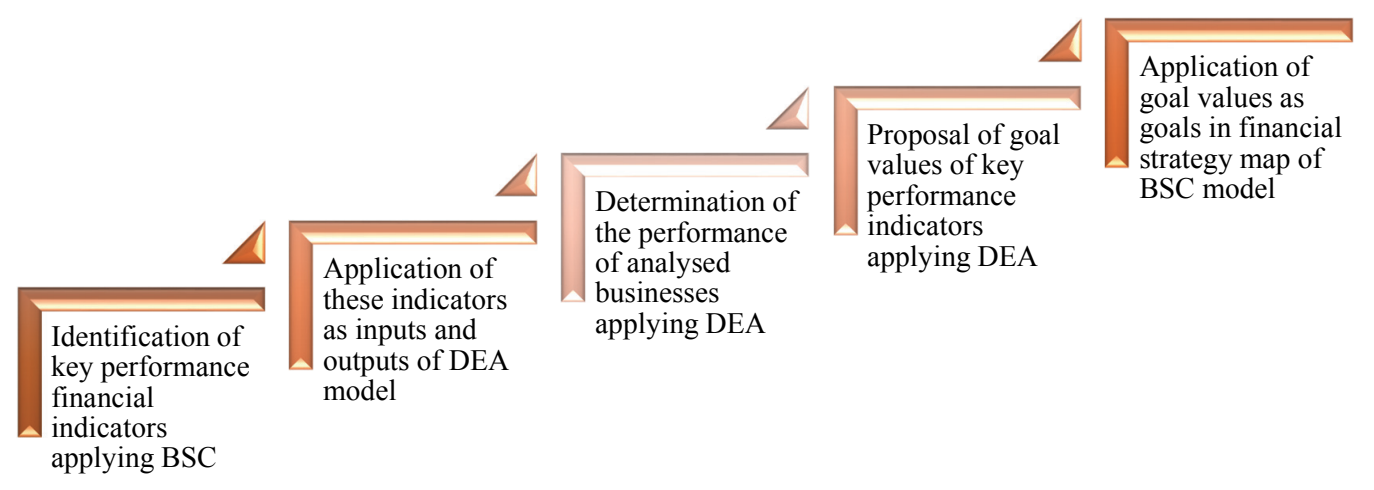

Fig. 1. Flowchart of the research 
The following financial indicators were applied to analyse the performance and financial health of the sample: TL - Total liquidity, CL - Current liquidity, ACP - Average collection period, IT - Inventory turnover, CPP - Creditor payment period, CTC - Cash - to - cash, TATR - Total assets turnover ratio, ROA - Return on assets, ROE - Return on equity, ROS - Return on sales, ER - Equity ratio, IR - Indebtedness ratio, OC - Overcapitalization, CR - Cost ratio, MCR - Material cost ratio, PCR - Personal cost ratio, EVAROS - Profitability with EVA indicator. These financial indicators represent all areas of financial and business performance assessment.

It was necessary to select key performance indicators that would meet the requirements of the analysed sample of companies from the above-mentioned indicators. When selecting these key performance indicators, the BSC method and correlation matrix were applied.

We used a correlation matrix to analyse relationships between selected financial indicators. The correlation matrix that is used to assess correlations between the variable pairs is a symmetric matrix $R=\left(\rho_{i j}\right)_{i, j=1, \ldots .}$, where

- $\rho_{i i}=1, i=1, \ldots, n$,

- $\rho_{i j}=\rho\left(X_{i}, X_{j}\right), i, j=1, \ldots, n$, is the correlation coefficient of random variables $X_{i}, X_{j}$, takes val-

ues from the interval $\langle-1,1\rangle$. The numerical value indicates strength of the linear relationship and the sign determines the direction of the relationship - direct, indirect. The value close to 1 expresses a strong positive (direct) relationship and the value close to -1 expresses a strong negative (indirect) linear relationship between the variables. If the correlation coefficient is nearly zero, it does not mean that there is no relationship between the variables, it means that the relationship can be non-linear (Hudec et al., 2007).

The correlation matrix consists of the correlation coefficient values from all possible variables pairs. It can be expressed as follows (Hudec et al., 2007):

$$
R=\left(\begin{array}{cccc}
1 & \rho_{12} & \cdots & \rho_{1 n} \\
\rho_{21} & 1 & \cdots & \rho_{2 n} \\
\vdots & \vdots & \ddots & \vdots \\
\rho_{n 1} & \rho_{n 2} & \cdots & 1
\end{array}\right)
$$

The correlation matrix mentioned above is processed using Statistica. This software highlighted correlation coefficients in the correlation matrix, where $\mathrm{p}$ is lower than the chosen significance level $\alpha=0.05$. To interpret the correlation coefficient we used the Cohen (1988) scale, according to which the absolute value of the correlation coefficient above 0.5 is interpreted as a strong correlation, the correlation coefficient value from 0.3 to 0.5 as a moderate correlation, the correlation coefficient value from 0.1 to 0.3 as a weak correlation and a correlation coefficient value below 0.1 as a trivial correlation.

The DEA method was applied to conduct a more detailed survey of business performance and financial health using key performance indicators. The DEA model was formulated as a one-step model for the BSC's financial perspective due to the lack of information on the customer perspective, the perspective of internal processes and the perspective of learning and growth. The key indicators identified by the BSC method and the correlation matrix were divided into DEA inputs and outputs.

The DEA model maximizes the efficiency of the rated unit $\mathrm{U}_{q}$, expressed as a share of the weighted outputs and weighted inputs, provided that the efficiency ratios of all other units are less than or equal to 1. For the unit $\mathrm{U}_{q}$ we get the weighted sum of inputs for the inputs $v_{i}, i=1,2, \ldots, m$, the weighted sum of outputs for the outputs $u_{k}, k=1,2, \ldots, r$, 


$$
\begin{aligned}
x_{q}^{\prime} & =\sum_{i=1}^{m} v_{i} x_{i q} \\
y_{\boldsymbol{q}}^{\prime} & =\sum_{k=1}^{r} u_{k} y_{k q}
\end{aligned}
$$

The DEA CCR model calculates the input and output weights based on optimized calculations so that it is as favourable as possible for the rated unit in terms of its efficiency (maximizing the efficiency of the rated unit) while maintaining the maximum unit efficiency of all other units. The whole model can be formulated for the unit $\mathrm{U}_{q}$ as the task of the linear programming as follows:

$$
\begin{array}{lr}
\max & \operatorname{ef}(\mathrm{U} q)=\frac{\sum_{k=1}^{r} u_{k} y_{k q}}{\sum_{i=1}^{m} v_{i} x_{i q}} \\
\text { subject to } & \frac{\sum_{k=1}^{r} u_{k} y_{k j}}{\sum_{i=1}^{m} v_{i} x_{i j}} \leq 1
\end{array}
$$

where $j=1,2, \ldots n ; k=1,2 \ldots r ; i=1,2 \ldots m ;, u_{k} \geq \varepsilon, v_{i} \geq \varepsilon, \operatorname{ef}\left(\mathrm{U}_{q}\right)$ is the unit's efficiency $\mathrm{U}_{q}, \varepsilon$ is an infinitesimal constant based on which the model ensures that all input and output weights will be positive and will thus be included in the model at least minimally, $x_{i j}, i=1,2, \ldots, m, j=1,2, \ldots, n$ is the $\mathrm{x}_{\mathrm{i}}$ input value per unit $\mathrm{U}_{j}$ and $y_{k j}, k=1,2, \ldots, r, j=1,2, \ldots, n$ is the value of the $\mathrm{y}_{k}$ output per unit $\mathrm{U}_{j}$. Input and output values are arranged in $\mathrm{X}$ and $\mathrm{Y}$ matrices that have a dimension $(m, n)$ or $(r, n)$.

The model (3) is not linear in its objective function as the function is the ratio of two linear functions. Using the Charnes-Cooper transformation, this task can be simply linearized. Two equivalent procedures can be used for this transformation. The first one maximizes the numerator's objective function of the model (3), provided that the denominator $=1$. The second procedure minimizes the denominator, provided that the numerator $=1$. We thus get two models (4) and (5) as could be seen below:

$$
\begin{array}{ll}
\max & \theta\left(\mathrm{U}_{q}\right)=\sum_{k=1}^{r} u_{k} y_{k q} \\
\text { subject to } & \sum_{k=1}^{r} u_{k} y_{k j}-\sum_{i=1}^{m} v_{i} x_{i j} \leq 0 \\
& \sum_{i=1}^{m} v_{i} x_{i q}=1 \\
& u_{k} \geq \varepsilon \\
& v_{i} \geq \varepsilon \\
& \\
\min & \phi\left(\mathrm{U}_{q}\right)=\sum_{i=1}^{m} v_{i} x_{i q} \\
\text { subject to } & \sum_{k=1}^{r} u_{k} y_{k j}-\sum_{i=1}^{m} v_{i} x_{i j} \leq 0 \\
& \sum_{k=1}^{r} u_{k} y_{k q}=1 \\
& u_{k} \geq \varepsilon \\
& v_{i} \geq \varepsilon
\end{array}
$$

The model (4) returns the optimal value to the objective function $\theta\left(\mathrm{U}_{q}\right) \leq 1$ with the value 1 indicating that the unit lies at the efficiency frontier and the value lower than 1 determines the inefficient units. This model is referred to as (primary): Input-oriented CCR model; the model (5) is referred to as Outputoriented CCR model. 
The procedure for constructing output-oriented CCR DEA models is almost analogous to input-oriented models. Their optimal value of objective function is $\phi^{*}\left(\mathrm{U}_{q}\right) \geq 1$. The value 1 is again assigned to efficient units and the value greater than 1 is assigned to those inefficient. If the unit is not efficient, it is possible to obtain the coordinates of the virtual unit, i.e. recommendation how the rated entity should improve its behaviour to reach the efficiency frontier using optimal variables (weights) from models (4) or (5). These models are sometimes referred to as multiplier models that have $(m+r)$ variables and $(n+$ $m+r+1)$ constraints. In order to evaluate the efficiency of the entire set of units, these models must be addressed for each unit separately. Therefore, it is necessary to address $n$ linear programming problems of this range. Because the number of units may be very large, it may be easier to work with dual models in case of models (4) and (5), which are also referred to as envelopment models (Jablonský \& Dlouhý, 2015).

Kočišová (2012) presents dual models as follows: In all linear programming tasks, a large number of constraints negatively affect the ability to solve the problem. For each linear problem, it is possible to construct a dual linear programming model that uses the same data and reduces the number of model constraints.

Klieštik (2009) considers that in terms of interpretation, a dual input-oriented model is more advantageous and, more importantly, more practical to work with. In this case, the dual problem to (4) is to have $(m+r)$ constraints and $(n+m+r+1)$ variables. Variables $\lambda_{j}, j=1,2, \ldots, \mathrm{n}$, are dual variables that belong to the first set of constraints (4), $\theta_{q}$ is a scalar dual variable that is associated with another restriction and $s k^{+}, k=1,2, \ldots, r$ a $s_{i}{ }^{-}, i=1,2, \ldots, m$ are the dual variables assigned to the lower intervals for the output and input weights.

Dual CCR input-oriented model can be written as follows:

$$
\begin{array}{ll}
\min & \theta_{q}-\varepsilon\left(\sum_{i=1}^{m} s_{i}^{-}+\sum_{k=1}^{r} s_{k}^{+}\right) \\
\text {subject to } & \sum_{j=1}^{n} x_{i j} \lambda_{j}+s_{i}^{-}=\theta_{q} x_{i q} \\
& \sum_{j=1}^{n} y_{k j} \lambda_{j}-s_{k}^{+}=y_{k q} \\
& \lambda_{j} \geq, s_{i}^{-} \geq 0, s_{k}^{+} \geq 0
\end{array}
$$

When we realize that $s_{k}{ }^{+}, k=1,2, \ldots, r$ a $s_{i}{ }^{-}, i=1,2, \ldots, m$, are actually additional variables under the constraints of model (6) and $\varepsilon$ is an infinitesimal constant, then this model can be written as follows (Charnes et al., 1978):

$$
\begin{array}{ll}
\min & \theta_{q} \\
\text { subject to } & \sum_{j=1}^{n} x_{i j} \lambda_{j} \leq \theta_{q} x_{i q} \\
& \sum_{j=1}^{n} y_{k j} \lambda_{j} \geq y_{k q} \\
& \lambda_{j} \geq 0
\end{array}
$$

The vector components $\lambda=\left(\lambda_{1}, \lambda_{2}, \ldots, \lambda_{n}\right), \lambda=\geq 0$ can be interpreted as weights (or coefficients of linear combination) that are assigned to individual units of the evaluated file. The aim of the model (7) is to find a linear combination of inputs and outputs of all units so that inputs and outputs of this combination are not worse (i.e. not higher for inputs and lower for outputs) as inputs and outputs of the evaluated unit $\mathrm{U}_{q}$. As shown by the link to the primary model (4), $\theta_{q}$ is the indicator of efficiency of the unit.

Dual output-oriented CCR model - dual model to the model of Banker et al. (1984) (5): 


$$
\begin{array}{ll}
\max & \phi_{q}+\varepsilon\left(\sum_{i=1}^{m} s_{i}^{-}+\sum_{k=1}^{r} s_{k}^{+}\right) \\
\text {subject to } & \sum_{j=1}^{n} x_{i j} \lambda_{j}+s_{i}^{-}=x_{i q} \\
& \sum_{j=1}^{n} y_{k j} \lambda_{j}-s_{k}^{+}=\phi_{q} y_{k q} \\
& \lambda_{j} \geq 0, s_{i}^{-} \geq 0, s_{k}^{+} \geq 0
\end{array}
$$

The model (8) returns the optimal value of the radial variable $\phi_{q}^{*} \geq 1$, which can be considered as the measure of efficiency of the evaluated unit $\mathrm{U}_{q}$, indicating the need for a proportional increase of all outputs to reach the efficiency frontier. Value $\phi_{q}^{*}=1$ indicates the efficiency of the unit.

Company performance analysis has to be carried out on a test sample of companies, as the DEA solution for such a large sample of companies would be very demanding. The Altman model was applied to select test samples. The model was created by modifying the original model. The result is suitable for companies whose securities are not traded on the securities market. This change brought about a revolutionary change in the $\mathrm{X}_{4}$ indicator, while the market valuation of equity changed to the accounting valuation (Sulub, 2014). Altman also proposed new weights for individual indicators and thresholds for the classification of companies that face or does not face bankruptcy. We have chosen the Altman model because it is one of the most frequently used prediction models in Slovakia. This model was used for comparison with the results of the DEA model by the authors Vavřina et al. (2013).

The equation of the modified Altman model is as follows:

$$
Z=0,717 \times x_{1}+0,847 \times x_{2}+3,10 \times x_{3}+0,420 \times x_{4}+0,998 \times x_{5}
$$

where $x_{1}$ is Net working capital / Equity, $x_{2}$ is a Retained earnings / Equity, $x_{3}$ is EBIT / Assets, $x_{4}$ is the Book value of equity / Book value of debt, $x_{5}$ is Sales / Assets.

Business classification zones:

$\mathrm{Z}>2.9 \rightarrow$ safe zone,

$Z \in<1.23 ; 2.9>\rightarrow$ grey zone,

$\mathrm{Z}<1.23 \rightarrow$ zone of threat - businesses heading towards bankruptcy.

\section{Results and discussion}

In order to analyse financial health and performance, financial indicators were selected from all areas of the company's financial health assessment, including selected operational indicators. Descriptive statistics of selected financial indicators of the analysed sample is shown in Table 2 . The analysed companies do not have a liquidity problem. The average value of the total liquidity is 3.92 and the current liquidity is 3.82. Liquidity values show that these companies work with minimal stocks, which is also reflected in the Inventory turnover. The median of the Total liquidity and Current liquidity indicate that half of the analysed sample of companies reaches values above 0.9 , which can be considered a positive phenomenon. These companies struggle with a high Creditor payment period, and as a result they have a negative Cash-to-cash. Total assets turnover ratio averages 0.8 , median equals 0.3 . It follows that the total assets of the analysed sample of companies are turned over less than once a year. When evaluating profitability, we focused on three indicators - ROA, ROE, and ROS. The average value of ROA indicator is 5.6\%, with a median of $4.5 \%$, so it can be assumed that half of the businesses analysed have a ROA of more than $4.5 \%$. The average value of ROE is $14.9 \%$, which is highly positive. The capital structure of these companies ranges from $20 \%$ to $80 \%$ in favour of external sources, which may be the reason for lower stability of these companies. From the point of view of the average value of the Overcapitalization, these 
are highly overcapitalized companies, however the median value of this indicator is low. Cost ratio is on average $96 \%$, which is also confirmed by the median. It follows that the average profitability of these companies is at the level of 4 cents to 1 EUR. Costs are made on average by material costs $(28 \%)$ and wage costs (only 4\%). The negative values of the EVAROS indicator indicate that the analysed sample of companies has performance problems. Thus, based on the calculated values of the selected financial indicators and the performance as well as the market valuation of the equity, the analysed sample shows performance problems.

Table 2

Descriptive statistics

\begin{tabular}{|c|c|c|c|c|c|c|}
\hline \multirow[b]{2}{*}{ Indicator } & \multicolumn{6}{|c|}{ Descriptive statistics } \\
\hline & Valid N & Average & Median & $\min$ & $\max$ & Std. Dev. \\
\hline TL & 295 & 3.923 & 0.9511 & 0.022 & 95.207 & 11.6489 \\
\hline CL & 295 & 3.824 & 0.8717 & 0.02 & 93.632 & 11.4986 \\
\hline $\mathrm{ACP}$ & 295 & 101.744 & 52.5057 & -28.994 & 824.716 & 135.7802 \\
\hline IT & 295 & 10.615 & 0.2574 & 0 & 206.652 & 30.947 \\
\hline CPP & 295 & 228.515 & 178.7012 & 0 & 1163.187 & 202.8765 \\
\hline CTC & 295 & -116.156 & -84.08 & -863.975 & 420.509 & 191.7345 \\
\hline TATR & 295 & 0.885 & 0.3092 & 0 & 9.926 & 1.4876 \\
\hline ROA & 295 & 0.056 & 0.0454 & -0.894 & 2.071 & 0.1589 \\
\hline ROE & 295 & 0.149 & 0.1256 & -15.737 & 4.52 & 1.2844 \\
\hline ROS & 295 & 0.056 & 0.0342 & -3.902 & 6.349 & 0.5622 \\
\hline ER & 295 & 0.211 & 0.1662 & -0.936 & 0.983 & 0.288 \\
\hline IR & 295 & 0.789 & 0.8338 & 0.017 & 1.936 & 0.288 \\
\hline $\mathrm{OC}$ & 295 & 5.06 & 0.2608 & -1.507 & 1155.15 & 67.4414 \\
\hline CR & 295 & 0.963 & 0.9608 & -0.252 & 4.896 & 0.3738 \\
\hline MCR & 295 & 0.281 & 0.1757 & 0 & 1.132 & 0.2846 \\
\hline PCR & 295 & 0.038 & 0.0102 & -0.001 & 0.24 & 0.0531 \\
\hline EVAROS & 295 & -0.045 & -0.0016 & -11.56 & 6.124 & 0.881 \\
\hline
\end{tabular}

The correlation matrix is a suitable tool for identifying key business performance indicators. The correlation matrix was applied to select key performance indicators for the financial perspective of BSC. These performance indicators are simultaneously the DEA inputs/outputs. The results of the correlation matrix are shown in Table 3.

The results of the correlation matrix show the proportional relationship between the TL, CL and CTC as well as the inversely proportional relationship between TL, CL and MCR. ACP shows an inversely proportional relationship with MCR and a direct proportional relationship with TATR. CPP shows an inversely proportional relationship with ROS and ER, and directly proportional relationship with CR and IR. The relationship between these indicators and the CPP was also recorded. ROS and CR show strong inversely proportional relationship.

The second set of information captures the relationship between the indicator EVAROS and the selected set of indicators. Based on the results of the correlation matrix, it is possible to confirm the statistically significant inversely proportional relationship between EVAROS and CPP. The correlation coefficient, which records the relationship between EVAROS and ROS indicators, is equal to 1. It follows that despite the different input in the form of the economic result, there is a strong direct relationship between these indicators, which makes it possible to state that EVA has a significant relation to the net profit value. This is confirmed by the significant, inversely proportional relationship between EVAROS and CR.

The relationship between EVAROS and the liquidity ratios was not confirmed in the correlation matrix. This is because these indicators are not the immediate determinants of performance, and at the same time it can be argued that the analysed sample of companies does not have an immediate liquidity problem. Also, the relationship between TATR and EVAROS was not confirmed. This non-existing relationship is, from our point of view, a big surprise compared to the previous findings as TATR is a key indicator 
of performance and its driving force. This will be the subject to our further analysis. The weak relationship with EVAROS was also recorded for ER, IR and PCR.

The results of the descriptive statistics and correlation matrix are an important input for creating the financial perspective of the BSC strategy map. For the purpose of knowing management of business performance, we have constructed a financial strategy management map (Fig. 2) with key performance indicators.

Table 3

Correlation matrix

\begin{tabular}{|c|c|c|c|c|c|c|c|c|c|c|c|c|c|c|c|c|c|}
\hline \multirow[b]{2}{*}{ Variable } & \multicolumn{17}{|c|}{ Correlations, Marked correlations are significant at $p<, 05000 \mathrm{~N}=295$} \\
\hline & TL & CL & $\mathbf{A C P}$ & IT & CPP & CTC & TATR & ROA & ROE & ROS & ER & IR & OC & CR & MCR & PCR & EVAROS \\
\hline \multirow[t]{2}{*}{$\overline{T L}$} & 1.0000 & 8 & 39 & 235 & 174 & & 29 & 88 & 19 & 56 & -.0132 & 32 & .0009 & 0162 & 1673 & -.0496 & 65 \\
\hline & & 0.00 & .123 & & & & & $\mathrm{p}=.872$ & & $\mathrm{p}=.760$ & & & $\mathrm{p}=.987$ & $\mathrm{p}=.767$ & $=.002$ & & \\
\hline \multirow[t]{2}{*}{ CL } & .9998 & 1.0000 & .0845 & -.0237 & -.0171 & .1578 & -.0833 & .0101 & .0131 & .0164 & -.0131 & .0131 & .0013 & -.0159 & -.1682 & -.0494 & .0163 \\
\hline & 0.00 & $\mathrm{p}=---$ & $\mathrm{p}=.120$ & $\mathrm{p}=.664$ & $\mathrm{p}=.753$ & & $\mathrm{p}=.125$ & $\mathrm{p}=.853$ & & $\mathrm{p}=.764$ & $\mathrm{p}=.810$ & & $\mathrm{p}=.981$ & $\mathrm{p}=.770$ & $\mathrm{p}=.002$ & $\mathrm{p}=.364$ & $=.764$ \\
\hline \multirow[t]{2}{*}{ ACP } & .0839 & .0845 & 1.0000 & -.0189 & -.0098 & .0200 & .1477 & .0103 & .0192 & .0090 & -.0548 & .0548 & -.0160 & -.0088 & -.1369 & -.0467 & .0090 \\
\hline & $\mathrm{p}=.123$ & $\mathrm{p}=.120$ & $\mathrm{p}=---$ & $\mathrm{p}=.729$ & $\mathrm{p}=.858$ & $\mathrm{p}=.714$ & & $\mathrm{p}=.850$ & $\mathrm{p}=.724$ & $\mathrm{p}=.869$ & & $\mathrm{p}=.313$ & $\mathrm{p}=.769$ & $\mathrm{p}=.872$ & $\mathrm{p}=.012$ & $\mathrm{p}=.390$ & $\mathrm{p}=.869$ \\
\hline \multirow[t]{2}{*}{ IT } & -.0235 & -.0237 & -.0189 & 1.0000 & .0601 & -.0178 & -.0463 & -.0213 & -.0330 & -.0154 & & .0587 & -.0060 & -.0039 & .0091 & .1820 & -.0132 \\
\hline & $\mathrm{p}=.666$ & $\mathrm{p}=.664$ & $\mathrm{p}=.729$ & $\mathrm{p}=---$ & $\mathrm{p}=.269$ & $\mathrm{p}=.744$ & $\mathrm{p}=.395$ & $\mathrm{p}=.695$ & $\mathrm{p}=.544$ & $\mathrm{p}=.777$ & $\mathrm{p}=.280$ & $\mathrm{p}=.280$ & $\mathrm{p}=.913$ & $\mathrm{p}=.943$ & $\mathrm{p}=.868$ & $\mathrm{p}=.001$ & $\mathrm{p}=.808$ \\
\hline \multirow{2}{*}{ CPP } & & & & & 1.0000 & & & & & & & & -.0049 & .9979 & .0272 & .1353 & \\
\hline & $\mathrm{p}=.750$ & $\mathrm{p}=.753$ & $\mathrm{p}=.858$ & $\mathrm{p}=.269$ & $\mathrm{p}=---$ & $\mathrm{p}=.781$ & $\mathrm{p}=.544$ & $\mathrm{p}=.698$ & $\mathrm{p}=.884$ & $p=0.00$ & $\mathbf{p}=.007$ & $\mathbf{p}=.007$ & $\mathrm{p}=.929$ & $p=0.00$ & $\mathrm{p}=.617$ & $\mathrm{p}=.013$ & $p=$ \\
\hline \multirow{2}{*}{ CTC } & & & & & & & & & & & & & & & & & \\
\hline & $p=.004$ & $p=.004$ & $\mathrm{p}=.714$ & $\mathrm{p}=.744$ & $\mathrm{p}=.781$ & $\mathrm{p}=---$ & $\mathrm{p}=.207$ & $\mathrm{p}=.873$ & $\mathrm{p}=.889$ & $\mathrm{p}=.787$ & $\mathrm{p}=.273$ & $\mathrm{p}=.273$ & $\mathrm{p}=.768$ & $\mathrm{p}=.792$ & $\mathrm{p}=.026$ & $\mathrm{p}=.427$ & $\mathrm{p}=.787$ \\
\hline \multirow[t]{2}{*}{ TATR } & -.0829 & -.0833 & .1477 & -.0463 & -.0330 & -.0686 & 1.0000 & .0346 & .0108 & .0311 & .0959 & -.0959 & .0211 & -.0305 & -.0001 & -.0 & .0311 \\
\hline & $\mathrm{p}=.127$ & $\mathrm{p}=.125$ & $p=.006$ & $\mathrm{p}=.395$ & $\mathrm{p}=.544$ & $\mathrm{p}=.207$ & $\mathrm{p}=---$ & $\mathrm{p}=.525$ & $\mathrm{p}=.843$ & $\mathrm{p}=.568$ & $\mathrm{p}=.077$ & $\mathrm{p}=.077$ & $\mathrm{p}=.698$ & $\mathrm{p}=.575$ & $\mathrm{p}=.999$ & $\mathrm{p}=.373$ & $\mathrm{p}=$. \\
\hline \multirow[t]{2}{*}{ ROA } & .0088 & .0101 & .0103 & -.0213 & -.0211 & -.0087 & .0346 & 1.0000 & .3817 & .0213 & .1788 & -.1788 & .0 & -.0 & -.2 & -.0 & .0 \\
\hline & $\mathrm{p}=.872$ & $\mathrm{p}=.853$ & $\mathrm{p}=.850$ & $\mathrm{p}=.695$ & $\mathrm{p}=.698$ & $\mathrm{p}=.873$ & $\mathrm{p}=.525$ & $\mathrm{p}=---$ & $p=.000$ & $\mathrm{p}=.695$ & $\mathrm{p}=.001$ & $\mathrm{p}=.001$ & $\mathrm{p}=.732$ & $\mathrm{p}=.704$ & $\mathrm{p}=.000$ & $\mathrm{p}=.138$ & $p=.691$ \\
\hline \multirow[t]{2}{*}{ ROE } & .0119 & .0131 & .0192 & -.0330 & .0080 & .0076 & .0108 & .3817 & 1.0000 & -.0090 & -.0041 & .0041 & -.0008 & .0090 & & -.05 & -.00 \\
\hline & $=827$ & $\mathrm{p}=.810$ & $\mathrm{p}=.724$ & $\mathrm{p}=.544$ & $\mathrm{p}=.884$ & $\mathrm{p}=.889$ & $\mathrm{p}=.843$ & $p=.000$ & $\mathrm{p}=---$ & $\mathrm{p}=.868$ & $\mathrm{p}=.941$ & $\mathrm{p}=.941$ & $\mathrm{p}=.988$ & $\mathrm{p}=.869$ & $\mathrm{p}=.001$ & $\mathrm{p}=.070$ & $\mathrm{p}=.871$ \\
\hline \multirow[t]{2}{*}{ ROS } & .0166 & .0164 & .0090 & -.0154 & -.9990 & & .0311 & .0213 & -.0090 & 1.0000 & .1450 & -.1 & .0046 & -.9998 & -.0254 & -.1 & 1.0 \\
\hline & $\mathrm{p}-.100$ & $\mathrm{p}=.764$ & $\mathrm{p}=.869$ & $\mathrm{p}=.777$ & $p=0.00$ & $\mathrm{p}-.10 /$ & $\mathrm{p}=.568$ & $\mathrm{p}=.695$ & $\mathrm{p}=.868$ & $\mathrm{p}=---$ & $\mathbf{p}=.007$ & $\mathrm{p}=.007$ & $\mathrm{p}=.932$ & $\mathrm{p}=\mathbf{0 . 0 0}$ & $\mathrm{p}=.641$ & $\mathrm{p}=.024$ & $p=0.00$ \\
\hline \multirow[t]{2}{*}{ ER } & -.0132 & -.0131 & -.0548 & -.0587 & -.1470 & -.0596 & .0959 & .1788 & -.0041 & .1450 & 1.0000 & -1.0000 & .0879 & -.1439 & .0288 & -.0069 & .1444 \\
\hline & $\mathrm{p}=.809$ & $\mathrm{p}=.810$ & $\mathrm{p}=.313$ & $\mathrm{p}=.280$ & $p=.007$ & $\mathrm{p}=.273$ & $\mathrm{p}=.077$ & $p=.001$ & $\mathrm{p}=.941$ & $p=.007$ & $\mathrm{p}=---$ & $\mathrm{p}=---$ & $\mathrm{p}=.106$ & $p=.008$ & $\mathrm{p}=.597$ & $\mathrm{p}=.899$ & $p=.008$ \\
\hline \multirow[t]{2}{*}{ IR } & .0132 & .0131 & .0548 & & .1470 & .0596 & -.0959 & -.1788 & .0041 & -.1450 & -1.0000 & 1.0000 & -.0879 & .1439 & -.0288 & .0069 & -.1444 \\
\hline & $\mathrm{p}=.809$ & $\mathrm{p}=.810$ & $\mathrm{p}-.315$ & $\mathrm{p}=.280$ & $\mathrm{p}=.007$ & $\mathrm{p}=.273$ & $\mathrm{p}=.077$ & $p=.001$ & $\mathrm{p}=.941$ & $\mathbf{p}=.007$ & $\mathrm{p}=---$ & $\mathrm{p}=---$ & $\mathrm{p}=.106$ & $\mathrm{p}=.008$ & $\mathrm{p}=.597$ & $\mathrm{p}=.899$ & $p=.008$ \\
\hline \multirow[t]{2}{*}{ OC } & .0009 & .0013 & -.0160 & -.0060 & -.0049 & -.0160 & .0211 & .0186 & -.0008 & .0046 & .0879 & -.0879 & 1.0000 & -.0046 & -.0407 & -.0131 & .0046 \\
\hline & $\mathrm{p}=.987$ & $\mathrm{p}=.981$ & $\mathrm{p}=.769$ & $\mathrm{p}=.913$ & $\mathrm{p}=.929$ & $\mathrm{p}=.768$ & $\mathrm{p}=.698$ & $\mathrm{p}=.732$ & $\mathrm{p}=.988$ & $\mathrm{p}=.932$ & $\mathrm{p}=.106$ & $\mathrm{p}=.106$ & $\mathrm{p}=---$ & $\mathrm{p}=.933$ & $\mathrm{p}=.455$ & $\mathrm{p}=.810$ & $\mathrm{p}=.932$ \\
\hline \multirow[t]{2}{*}{ CR } & -.0162 & -.0159 & -.0088 & -.0039 & .9979 & -.0144 & -.0305 & -.0206 & .0090 & -.9998 & -.1439 & .1439 & -.0046 & 1.0000 & .0272 & .1243 & -.9998 \\
\hline & $\mathrm{p}=.767$ & $\mathrm{p}=.770$ & $\mathrm{p}=.872$ & $\mathrm{p}=.943$ & $p=0.00$ & $\mathrm{p}=.792$ & $\mathrm{p}=.575$ & $\mathrm{p}=.704$ & $\mathrm{p}=.869$ & $p=0.00$ & $\mathrm{p}=.008$ & $\mathrm{p}=.008$ & $\mathrm{p}=.933$ & $\mathrm{p}=---$ & $\mathrm{p}=.618$ & $\mathrm{p}=.022$ & $p=0.00$ \\
\hline \multirow[t]{2}{*}{ MCR } & -.1673 & -.1682 & -.1369 & .0091 & .0272 & -.1208 & -.0001 & -.2579 & -.1717 & -.0254 & .0288 & -.0288 & -.0407 & .0272 & 1.0000 & .5615 & -.0257 \\
\hline & $p=.002$ & $p=.002$ & $\mathrm{p}=.012$ & $\mathrm{p}=.868$ & $\mathrm{p}=.617$ & $p=.026$ & $\mathrm{p}=.999$ & $p=.000$ & $p=.001$ & $\mathrm{p}=.641$ & $\mathrm{p}=.597$ & $\mathrm{p}=.597$ & $\mathrm{p}=.455$ & $\mathrm{p}=.618$ & $\mathrm{p}=---$ & $\mathrm{p}=\mathbf{0 . 0 0}$ & $\mathrm{p}=.637$ \\
\hline \multirow[t]{2}{*}{ PCR } & -.0496 & -.0494 & -.0467 & .1820 & .1353 & -.0432 & -.0485 & -.0806 & -.0984 & -.1227 & -.0069 & .0069 & -.0131 & .1243 & .5615 & 1.0000 & -.1232 \\
\hline & $\mathrm{p}=.362$ & $\mathrm{p}=.364$ & $\mathrm{p}=.390$ & $\mathrm{p}=.001$ & $p=.013$ & $\mathrm{p}=.427$ & $\mathrm{p}=.373$ & $\mathrm{p}=.138$ & $\mathrm{p}=.070$ & $p=.024$ & $\mathrm{p}=.899$ & $\mathrm{p}=.899$ & $\mathrm{p}=.810$ & $\mathrm{p}=.022$ & $\mathrm{p}=\mathbf{0 . 0 0}$ & $\mathrm{p}=---$ & $p=.023$ \\
\hline \multirow[t]{2}{*}{ EVAROS } & .0165 & .0163 & .0090 & -.0132 & -.9989 & .0147 & .0311 & .0216 & -.0088 & 1.0000 & .1444 & -.1444 & .0046 & -.9998 & -.0257 & -.1232 & 1.0000 \\
\hline & $\mathrm{p}=.761$ & $\mathrm{p}=.764$ & $\mathrm{p}=.869$ & $\mathrm{p}=.808$ & $p=0.00$ & $\mathrm{p}=.787$ & $\mathrm{p}=.568$ & $\mathrm{p}=.691$ & $\mathrm{p}=.871$ & $p=0.00$ & $\mathrm{p}=.008$ & $\mathrm{p}=.008$ & $\mathrm{p}=.932$ & $p=0.00$ & $\mathrm{p}=.637$ & $\mathrm{p}=.023$ & $\mathrm{p}=---$ \\
\hline
\end{tabular}

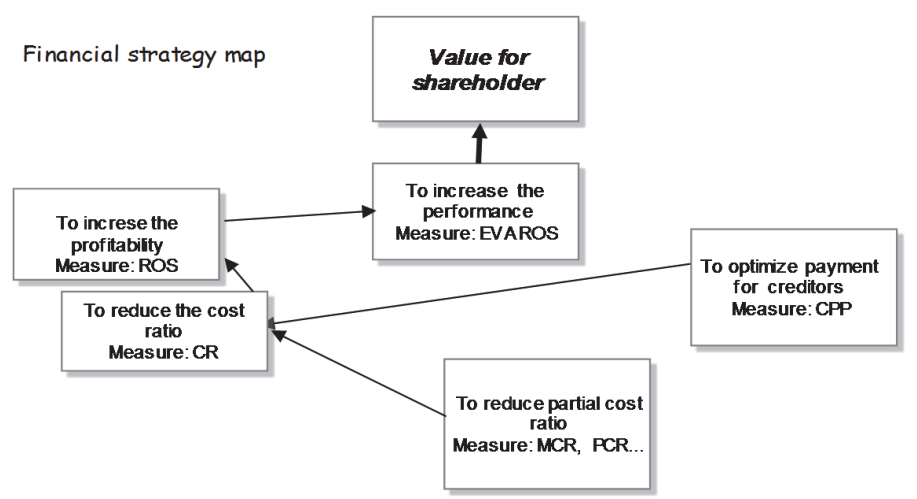

Fig. 2. Financial strategy management map

We made use of 5 companies that are according to Altman's model close to bankruptcy (TP6, TP7, TP24, TP12, TP19) and 5 companies (TP4, TP10, TP11, TP30, TP31) that are safe from bankruptcy. The calculation of financial health with the application of selected financial indicators (CR, CPP, MCR, ROE, 
ROS - 3 inputs and 2 outputs) was carried out using the input-oriented DEA model. We have formulated a dual linear programming model.

As an example of a dual model, we specify the objective function and constraints for the TP30 (DMU1) - it was placed in the first position.

$\min z=\theta_{1}$

where:

$$
\begin{aligned}
& 0.94 \lambda_{1}+0.95 \lambda_{2}+0.934 \lambda_{3}+0.95 \lambda_{4}+0.97 \lambda_{5}+0.98 \lambda_{6}+1.27 \lambda_{7}+0.99 \lambda_{8}+0.96 \lambda_{9}+0.98 \lambda_{10}-0.94 \theta_{1} \leq 0 \\
& 0.19 \lambda_{1}+0.25 \lambda_{2}+0.23 \lambda_{3}+0.13 \lambda_{4}+0.15 \lambda_{5}+1.39 \lambda_{6}+1.72 \lambda_{7}+0.36 \lambda_{8}+2.11 \lambda_{9}+1.43 \lambda_{10}-0.85 \theta_{1} \leq 0 \\
& 0.55 \lambda_{1}+0.53 \lambda_{2}+0.56 \lambda_{3}+0.66 \lambda_{4}+0.66 \lambda_{5}+0.57 \lambda_{6}+0.45 \lambda_{7}+0.44 \lambda_{8}+0.63 \lambda_{9}+0.60 \lambda_{10}-0.55 \theta_{1} \leq 0 \\
& 0.10 \lambda_{1}+0.50 \lambda_{2}+0.10 \lambda_{3}+0.11 \lambda_{4}+0.06 \lambda_{5}+0.07 \lambda_{6}+(-) 0.17 \lambda_{7}+0.02 \lambda_{8}+0.04 \lambda_{9}+0.04 \lambda_{10} \geq 0.10 \\
& 0.05 \lambda_{1}+0.04 \lambda_{2}+0.06 \lambda_{3}+0.04 \lambda_{4}+0.01 \lambda_{5}+0.02 \lambda_{6}+(-) 0.36 \lambda_{7}+0.01 \lambda_{8}+0.04 \lambda_{9}+0.02 \lambda_{10} \geq 0.05 \\
& \lambda_{1}+\lambda_{2}+\lambda_{3}+\lambda_{4}+\lambda_{5}+\lambda_{6}+\lambda_{7}+\lambda_{8}+\lambda_{9}+\lambda_{10 .} \text { - free } \\
& \lambda_{1}, \lambda_{2} \ldots \lambda_{10} \geq 0
\end{aligned}
$$

Then we calculated efficiency of the analysed sample. Results are shown in Table 4.

Table 4

Efficiency of the analysed sample

\begin{tabular}{lrrrrrr}
\hline Analysed businesses & CR & CPP & \multicolumn{1}{l}{ MCR } & \multicolumn{1}{l}{ ROE } & \multicolumn{1}{l}{ ROS } & \multicolumn{1}{l}{$\boldsymbol{\theta}$} \\
\hline TP30 & 0.94 & 0.19 & 0.55 & 0.10 & 0.05 & 0.98 \\
TP4 & 0.95 & 0.25 & 0.53 & 0.50 & 0.04 & 1.00 \\
TP10 & 0.93 & 0.23 & 0.56 & 0.10 & 0.06 & 1.00 \\
TP11 & 0.95 & 0.13 & 0.66 & 0.11 & 0.04 & 1.00 \\
TP31 & 0.97 & 0.15 & 0.66 & 0.06 & 0.01 & 0.27 \\
T6 & 0.98 & 1.39 & 0.57 & 0.07 & 0.02 & 0.37 \\
TP7 & 1.27 & 1.72 & 0.45 & -0.17 & -0.36 & 0.00 \\
TP24 & 0.99 & 0.37 & 0.44 & 0.02 & 0.01 & 0.14 \\
TP12 & 0.96 & 2.11 & 0.63 & 0.04 & 0.04 & 0.76 \\
TP19 & 0.98 & 1.43 & 0.60 & 0.04 & 0.02 & 0.37 \\
\hline
\end{tabular}

Based on the DEA analysis, we find that from the analysed sample of companies, three companies have an efficiency equal to 1 and one close to $1(0.98)$. These are the companies that have been evaluated by the Altman model as companies which are not threatened by bankruptcy. The only company that did not conform to the results of the Altman model is TP31. The second group of companies (TP6, TP7, TP24, TP12 and TP19) is made of those that are inefficient and therefore may face bankruptcy. The DEA has confirmed low efficiency and performance of all 5 companies. We would like to point out TP7 - a company which has a negative value of profitability. The DEA has evaluated this company as a zero-efficiency company due to this negative value.

The results of DEA model enable us to set goal values for key performance indicators that create the BSC strategy map. It should be noted that when studying articles on this issue, we did not find a link between BSC and DEA, which would result to the numerical expression of goal values. By achieving the goal values of key performance indicators, it is possible to increase the performance of the analysed companies. The application of correlation matrix for the selection of key performance indicators for DEA model is also the innovative solution.

One of the major input performance indicators is CPP indicator. Fig. 3 shows the comparison of the actual values of the $\left(\mathrm{CPP}_{\mathrm{a}}\right)$ and the goal values of this indicator for the sample of companies tested. 


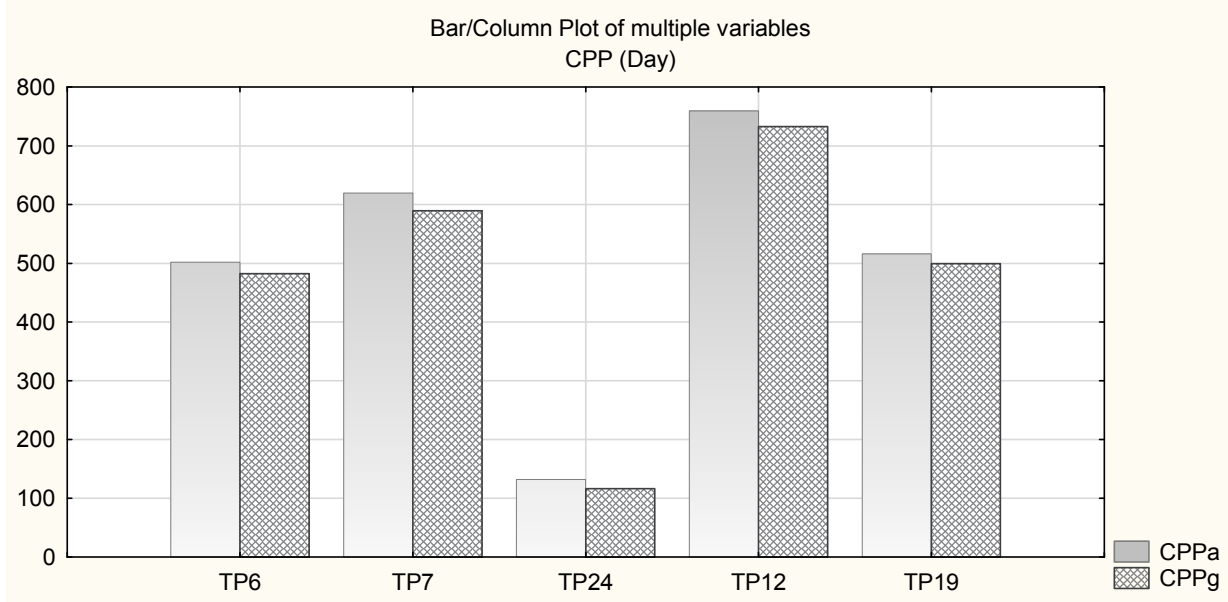

Fig. 3. Comparison of the actual and goal values of the CPP indicator

One of the significant output performance indicators is ROS indicator. The goal values of this indicator are to be found in Fig. 4.

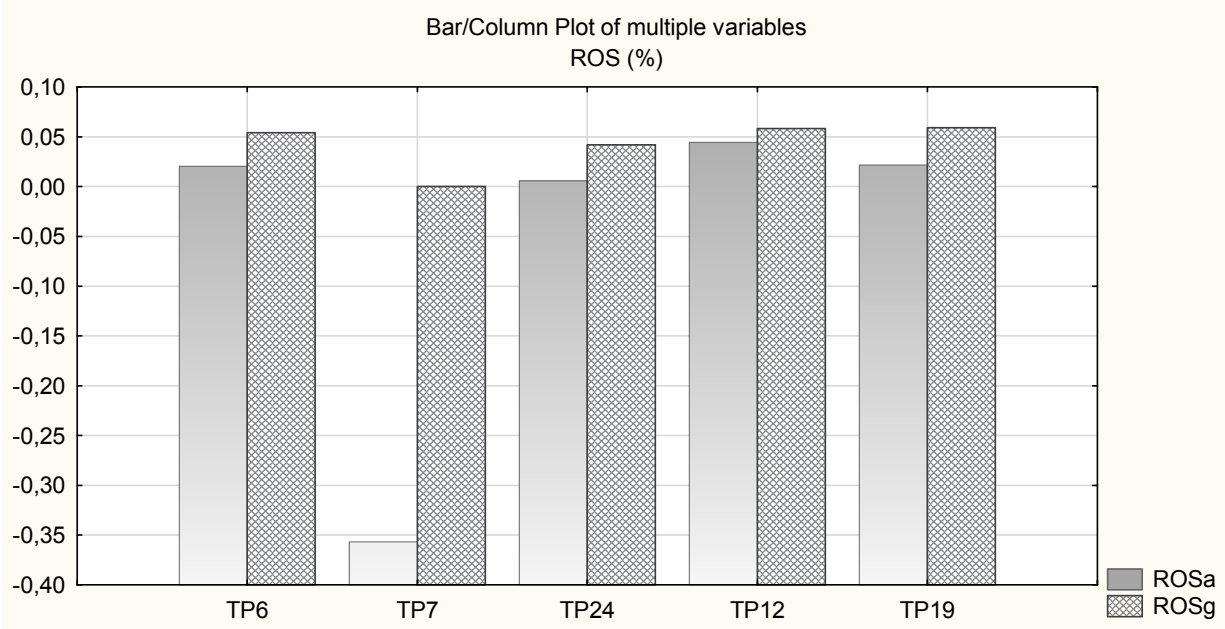

Fig. 4. Comparison of the actual and goal values of the ROS indicator

\section{Conclusion}

Successful implementation of the BSC method will achieve results that we can consider to be highly positive and beneficial. This method is suitable not only for companies in crisis but also for those that want to implement new visions and changes. The BSC method is being promoted mainly in the industrial sector, but also in companies providing services, especially financial services. It was proved that after its introduction, many financial parameters of these companies have improved, their value increased, costs got stabilized and liquidity increased. The results regarding the customer perspective in terms of retaining and acquiring new customers have also improved, thereby increasing the market share. New processes have emerged in the area of internal processes, particularly in the area of research and development. In many companies, more emphasis has been put on employees, their education and motivation.

In spite of the increasing efforts to suppress the relevance, suitability and applicability of financial indicators for assessing financial health and performance, these indicators remain the most important indicators from all perspectives of BSC. This is because they reflect the impact and consequences of all areas of business activities. However, traditional financial indicators are being replaced by new, more flexible ones that take into account a wider range of criteria and impact on future business development. These 
are the indicators that are based on the theory of Value based management and market principles. However, it is necessary to be aware of the fact that accounting and financial statements provide "typically distorted information" about the performance of a company. For example, there is no accounting document on the cost spent on equity. This cost has to be estimated. In this respect, the BSC system can bring enormous benefits, new insights and new possibilities for these calculations and evaluations.

DEA is a relatively new (compared to statistical and other methods) nonparametric method, one of many possible approaches to assessing the financial health of companies. As mentioned above, it was originally intended to evaluate the efficiency of production units. In contrast to traditional approaches to efficiency, this method allows an individual evaluation of a company and its individual production units with respect to a whole set of units. We see this as one of its greatest benefits. In addition to identifying financially sound units, it is possible to identify the source of financial distress and determine the way in which a company can reach the financial health frontier by reducing or increasing inputs or outputs (depending on model orientation). Other advantages of this method include the possibility of identifying a "reference unit" for a unit that causes or is in financial troubles. It turned out that the results of this method are comparable with the results of the Altman Z - score in the case of financial health predictions. This finding creates the preconditions for applying this method also in the field of prognosis of future success of a company or its failure.

Linking the BSC and DEA methods appears to be highly beneficial. The first step is to identify key performance indicators using the BSC principles and the second is to use these indicators as input/output values in the DEA model. Using DEA, we are able to find out which company is efficient and therefore financially sound. The advantage of this model is that it uses a combination of several input-output values when evaluating performance, making performance evaluation a more complex method. A major benefit of the DEA is its ability to calculate the goal values of key performance indicators. If these goal values are achieved by a company, it becomes efficient. The addition of the DEA method to BSC is a significant step forward in improving company performance.

\section{Acknowledgement}

This paper was prepared within the grant scheme VEGA no. 1/0887/17 - Increasing the competitiveness of Slovakia within the EU by improving efficiency and performance of production systems.

\section{References}

Andersen, H.V., Lawrie, G. \& Savič, N. (2004). Effective quality management through third-generation balanced scorecard. International Journal of Productivity and Performance Management, 53(7), 634645.

Antimonopoly Office of the Slovak Republic. (2013). Fungovanie a problémy v sektore tepelného hospodárstva v SR so zameraním na systémy CZT z pohl'adu Protimonopolného úradu SR. Retrieved December 21, 2018, from http://www.antimon.gov.sk/data/att/365.pdf.

Aryanezhad, M.B., Najafi, E., \& Farkoush, S.B. (2011). A BSC-DEA approach to measure the relative efficiency of service industry: A case study of banking sector. International Journal of Industrial Engineering Computations, 2(2), 273-282.

Asgari, S. D., Haeri, A., \& Jafari, M. (2017). Integration of Balanced Scorecard and Three- stage Data Envelopment Analysis Approaches. Iranian Journal of Management Studies, 10(2), 527-550.

Banker, R. D., Charnes, A., \& Cooper, W.W. (1984). Some models for estimating technical scale inefficiencies in data envelopment analysis. Management Science, 30(9), 1078-1092.

Blašková, M. (2011). Rozvoj l’udského potenciálu: Motivovanie, komunikovanie, harmonizovanie a rozhodovanie. Žilina: Žilinská univerzita,. 
Bullen, Ch. V., \& Rockart, J. F. (1981). A Primer on Critical Success Factors. Sloan working paper number. 1220-81, CISR no. 69. Center for Information Systems Research, Sloan School of Management, Massachusetts Institute of Technology. Retrieved January 15, 2019, from https://dspace.mit.edu/handle/1721.1/1988.

Clegg, S. R., \& Bailey, J. R. (2008). International Encyclopedia of Organization Studies. London: Sage Publications.

Cobbold, I., \& Lawrie, G. (2002). The development of the Balanced Scorecard as a strategic management tool. In Proceedings of Third International Conference on Performance Measurement and Management (PMA 2002).

Cohen, J. (1988). Statistical power analysis for the behavioral sciences. 2nd ed. Hillsdale, NJ: Lawrence Erlbaum Associates.

Committee on Non-Financial Measures of Effectiveness (1971). Report of the committee on non-financial measures of effectiveness. The Accounting Review, 46(4), 165-211.

Cooper, W., Seiford, L., \& Tone, K. (2007). A comprehensive Text with Models, Applications, References and DEA-Solver Software. 2nd ed. Springer US.

Cooper, W. W., Seiford, L. M., \& Zhu, J. (2011). Data Envelopment Analysis: History, Models and Interpretations. In W. W. Cooper et al. (Ed.), Handbook on Data Envelopment Analysis (pp. 1-39). New York: Springer.

Dearden, J. (1969). The case against ROI control. Harvard Business Review, 47(3), 124.

Dumitrescu, L. \& Fuciu, M. (2009). Balanced Scorecard - A New Tool for Strategic Management. Bulletin Scientific, 28(2), 37-42.

Durkáčová, M., \& Kádarová, J. (2014). Návrh inovatívneho modelu integrácie BSC a DEA. Výkonnost' podniku, 4(1), 28-36. Retrieved August 4, 2018, from http $>/ /$ www.vusem.sk/public/userfiles/ files/VP1_2014.pdf.

Färe, R., Grosskopf, S., Lindgren, B., \& Roose, P. (1992). Productivity changes in Swedish analysis pharmacies 1980-1989: A nonparametric Malmquist approach. Journal of Productivity, 3(1-2), 85101.

Farrell, M. J. (1957). The measurement of productive efficiency. Journal of the Royal Statistical Society, Series A, 120(3), 253-290.

Gallo, P. (2017). Moderné systémy riadenia organizácie založené na zvyšovaní jej výkonnosti Controlling a finančno-manažérske teórie v praxi, 4(1). Retrieved July 31, 2018, from http://www.dominanta.sk/Clanok_2017_05_ModSysRiad.pdf.

Gavurová, B. (2011). Systém Balanced Scorecard v podnikovom riadení. Ekonomický časopis, 59(2), 163-176.

Gavurová, B. (2012). Source identification of potential malfunction of Balanced Scorecard system and its influence on system function. E+M Ekonomie a Management, 15(3), 76-90.

Hasan, H. \& Tibbits, H. (2000). Strategic management of electronic commerce: an adaptation of the Balanced Scorecard. Internet Research, 10(5), 439-450..

Horváthová, J., \& Suhányiová, A. (2012). Balanced Scorecard - Nástroj riadenia podnikov a ich udržatel'nosti v čase krízy. In Management Challenges in the 21th century 2012 (pp. 232-247). [cit.2018-08-01]. Trenčín: City University. Retrieved August 1, 2018, from http://www.cutn.sk/Library/proceedings/mch 2012/edito-

vane_prispevky/Horv\%C3\%A1 thov\%C3\%A1_Suh\%C3\%A1nyiov\%C3\%A1.pdf.

Horváthová, J., \& Mokrišová, M. (2017). Innovative approaches and their application in measuring business performance. In Proceedings of $C B U$ International conference on innovations in science and education (pp. 178-183). CBU Research Institute s.r.o. http://dx.doi.org/10.12955/cbup.v5.921.

Hudec, O., Sisáková, J., Tartal'ová, A., \& Želinský, T. (2007). Štatistické metódy v ekonomických vedách. Košice: Ekonomická fakulta TUKE.

Charnes, A., Cooper, W. W. \& Rhodes, E. (1978). Measuring the efficiency of decision making units. European Journal of Operational Research, 2(6), 429-444.

Chung, K. H. (1987). Management: Critical success factors. Newton, MA: Allyn and Bacon, Inc. 
Jablonský, J., \& Dlouhý, M. (2015). Modely hodnocení efektivnosti a alokace zdrojů. Praha: Professional Publishing.

Kádárová, J. Durkáčová, M., Teplická, K. \& Kádár, G. (2015). The Proposal of an Innovative Integrated BSC-DEA Model. Procedia: Ecnomics and Finance - Proceedings from the 2nd GLOBAL CONFERENCE on BUSINESS, ECONOMICS, MANAGEMENT and TOURISM 2014, Vol 23 (pp. 1503-1508). Praha: Elsevier. https://doi.org/10.1016/S2212-5671(15)00375-5.

Kaplan, R. S. \& Norton, D. P. (1992). The balanced scorecard: Measures that drive performance. Harvard Business Review, 70(1), 71-79.

Kaplan, R. S. \& Norton, D. P. (1996). The Balanced Scorecard: Translating Strategy into Action (1th ed.). Boston: Harvard Business School Press.

Kaplan, R. S. \& Norton, D. P. (2007). Balanced Scorecard : Strategický systém méření výkonnosti podniku. Praha: Management Press.

Klieštik, T. (2009). Kvantifikácia efektivity činností dopravných podnikov pomocou Data Envelopment Analysis. E+M Ekonomie a management, 12(1), 133-145.

Kočišová, K., (2012). Aplikácia DEA modelov pri analýze technickej efektívnosti pobočiek komerčnej banky. Ekonomický časopis, 60(2), 169-186, Retrieved August 18, 2018, from https://www.sav.sk/journals/uploads/0622125302\%2012\%20Ko\%C4\%8Di\%C5\%A1 ov\%C3\%A1\%20RS.pdf.

Lawrie, J. G. \& Cobbold, I. (2004). Third generation balanced scorecard: Evolution of an effective strategic control tool. International Journal of Productivity and Perfomance Management, 53(7), 611623.

Lesáková, L. (2004). Metódy hodnotenia výkonnosti malých a stredných podnikov. Banská Bystrica: Univerzita Mateja Bela.

Lesáková, L., Dubcová, K., \& Gundová, P. (2017). The knowledge and use of the Balanced Scorecard method in businesses in the Slovak Republic. E+M Ekonomie a Management, 20(4), 49-58.

Lotfi, F. H., Sadjadi, S.J., Khaki, A., and Najafi, E. (2010). A combined Interval Net DEA and BSC for evaluating organizational efficiency. Applied Mathematical Sciences, 4(40), 1975-1999.

Madzík, P. (2017). Nástroje systematického riešenia problémov. Ružomberok: Verbum.

Majorová, M. (2007). Referenčné materiály k predmetu Optimálne programovanie II (čast' DEA Analýza dátových obalov). Nitra : Fakulta ekonomiky a manažmentu SPU.

Memari, F., Momeni, M., \& Ghasemi, A. R. (2014). Synthetic application of data envelopment analysis and balanced scorecard for systems performance Evaluation: A Review In International Research Journal of Applied and Basic Sciences, 8(10), 1525-1530.

Mooraj, S., Oyon, D., \& Hostettler, D. (1999). The Balanced scorecard:a necessary good or unnecessary evil? European Management Journal, 17(5), 481-491.

Nair, M. (2004). Essentials of Balanced Scorecard. New Yersey: John Wiley \& Sons, Inc., Hoboken.

Olve, N., Roy, J., \& Wetter, M. (1999), Performance Drivers: A Practical Guide to Using the Balanced Scorecard. Chichester: Wiley (English translation), first published in Swedish in 1997.

Peters, T. J., \& Waterman, R.H. (1982). Search of Excellence. New York: Harper and Row.

Petř́k, T. (2009). Ekonomické a finanční ř́zení firmy. Praha: Grada Publishing.

Quesado, P. R., Guzmán, B. A., \& Rodrigues, L. L. (2018). Advantages and contributions in the balanced scorecard implementation. Intangible Capital, 14(1), 186-201.

Rajnoha, R., Štefko, R., Merková, M., \& Dobrovič, J. (2016). Business intelligence as a key information and knowledge tool for strategic business performance management, E\&M Ekonomie a Management, 19(1), 183-203.

Rigby, D.K. (2001), Management tools and techniques: a survey, California Management Review, 43(2), $139-160$

Rigby, D.K. (2003), Management tools survey 2003: usage up as companies strive to make headway in tough times. Strategy \& Leadership, 31(5), 4-11.

Rouse, P., Putterill, M., \& Ryan, D. (2002). Integrated performance measurement design: insights from an application in aicraft maitenance. Management Accounting Research, 13(2), 229-248. 
Sulub, S. A. (2014). Testing the predictive power of Altman's revised Z' model: The case of 10 multinational companies. Research Journal of Finance and Accounting, 5(21), 174-184.

Tjader, Y., May, J.H., Shang, J. Vargas, L.G., \& Gao, N. (2014). Firm-level outsourcing decision making: A balanced scorecard- based analytic network proces model. International journal of Production Economics, 147(C), 614-623.

Vavřina, J., Hampel, D., \& Janová J. (2013). New approaches for the financial distress classification in agribusiness. Acta Universitatis Agriculturae et Silviculturae Mendelianae Brunensis, 61(4), 11771182.

Vrábliková, M. (2017). The business performance measurement as a tool of creation of the innovative intentions In Conference Proceedings from International Scientific Conference PEMF 2017, Vol. I (pp. 37-47). Ružomberok: Verbum. Retrieved August 1, 2018, from http://www.manazmentpp.sk/wpcontent/uploads/2018/01/Zborn\%C3\%ADk-PEMF2017.pdf.

Walderrama, T.G., Mulero-Mendigorri, E., \& Revuelta-Bordoy, D. (2009). Relating the perspectives of the balanced scorecard for R\&D by means of DEA. European Journal of Operational Research, 196(3), 1177-1189.

Werner, M. L., \& Xu, F. (2012). Executing Strategy with the Balanced Scorecard. International Journal of financial Research, 3(1). 88-94.

Zimermanová, K., \& Bartková, L. (2016). Využívanie vybraných nástrojov na analýzu konkurencie v MSP na Slovensku In Zborník z medzinárodnej vedeckej konfernecie Posolstvo Jána Pavla II. 2016: "Súčasné výzvy a trendy v ..." (pp.. 386-395). Ružomberok: VERBUM.

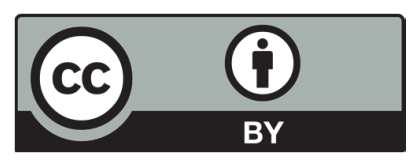

(C) 2019 by the authors; licensee Growing Science, Canada. This is an open access article distributed under the terms and conditions of the Creative Commons Attribution (CCBY) license (http://creativecommons.org/licenses/by/4.0/). 